\title{
A NEW VISION OF THE KNOWLEDGE ECONOMY
}

\author{
Brian Chi-ang Lin \\ National Chengchi University
}

\begin{abstract}
To date, more than half of the output in the major OECD countries has been knowledge based. This paper argues, however, that the current growthoriented exposition of the knowledge economy rooted in the conventional concept of free competition is insufficient for promoting the long-term development of human societies. Although we now live in a knowledge economy, most countries have been concurrently characterized by serious phenomena such as environmental degradation and growing economic inequality. The prospect of meeting global commitments, for instance, to reducing inequality, as outlined in the 1995 World Summit for Social Development in Copenhagen and endorsed in the United Nations Millennium Declaration, is bleak and the global society as a whole has become less and less sustainable. Indeed, the world is better seen as composed of numerous (but finite) knowledge economies. To take up the challenge of sustainable development of human societies, we have to develop a pluralistic perspective of the knowledge economy and fully acknowledge the characteristics of each unique knowledge system (such as indigenous knowledge possessed by a small tribe). Once we can help each individual knowledge system develop into a specific set of economic institutions that freely exchange concepts and beliefs with each other in a global environment, we will be able to develop a global economy that embodies a value-committed basis that assures a sustainable path of development on earth.
\end{abstract}

Keywords. Economic inequality; Growth; Indigenous knowledge; Sustainable development; The knowledge economy

There are changes in other spheres too which we must expect to come. When the accumulation of wealth is no longer of high social importance, there will be great changes in the code of morals ... . Of course there will still be many people with intense, unsatisfied purposiveness who will blindly pursue wealth - unless they can find some plausible substitute. But the rest of us will no longer be under any obligation to applaud and encourage them. (Keynes, 1963, pp. 369-370)

\section{Introduction}

The present interpretation of the knowledge economy (or knowledge-based economy) focuses mainly on the important role of knowledge or human capital in 
long-term economic growth (e.g. Grossman and Helpman, 1991; Freeman and Polasky, 1992; Jones, 1995; OECD, 1996; Aghion and Howitt, 1998; Neef, 1998; Mokyr, 2002; Paganetto, 2004; Carlaw et al., 2006). ${ }^{1}$ According to an OECD report (1996), it is estimated that more than half of the GDP in the major OECD countries is now knowledge based. Yet the unifaceted exposition of the knowledge economy from the perspective of increased production and accumulation has been far from perfect. Despite the fact that the share of knowledge production in GDP has been increasing over the past several decades, our human societies have been concurrently characterized by serious phenomena such as growing economic inequality (e.g. World Bank, 1997; United Nations, 2005) and environmental degradation (e.g. Yi, 2001; Murray and Cook, 2002; Diamond, 2005; Meadows et al., 2005).

To resolve the aforementioned problems and lead socioeconomic progress towards a sustainable society, it is necessary to develop a pluralistic perspective of the knowledge economy. Since the Brundtland Report was released in 1987, we have begun to inquire into the possibility of global sustainability through successive generations. Fundamental to this holistic perspective is the recognition that human generations are interrelated and that intergenerational issues such as equity, environmental externalities, allocation of (environmental) resources and policies for social optimality ought to be critically addressed (e.g. Howarth and Norgaard, 1990; Howarth, 1991; Babu et al., 1997; Farmer and Randall, 1997; Dasgupta, 1998; Ansuategi and Escapa, 2002; Farmer, 2005).

To thoroughly investigate the growth-oriented exposition of the knowledge economy, Section 2 first reviews the Austrian analysis of knowledge and the knowledge industries, which are considered the inspiration of the mainstream exposition. Section 3 examines the new growth theory, which considers knowledge and technological spillovers as the main sources of economic growth. Then, Section 4 analyses the lacunae of the knowledge economy, such as the growth of income and wealth inequality, and Section 5 briefly assesses the Austrian and mainstream approaches. To develop an alternative new vision of the knowledge economy, Section 6 analyses the evolution of knowledge and its impact on human development. Section 7 introduces indigenous knowledge, a unique intellectual knowledge system, which has been increasingly recognized as critical for sustainable development. Section 8 argues that the notion of sustainable development has in its roots John Stuart Mill's stationary state, an ideal and sustainable society compatible with Keynes's vision described in his Economic Possibilities for Our Grandchildren (1930). Section 9 offers a value-committed vision of the knowledge economy that helps emancipate the present growth-oriented capitalism, and Section 10 concludes.

\section{The Inception of Knowledge Industries: The Austrian Exposition of Knowledge}

The present interpretation of the knowledge economy emphasizes the significance of production, distribution and use of knowledge for economic growth. As early as 1962, Fritz Machlup, a late president of the American Economic Association (AEA) and an eminent Austrian economist, first analysed and coined the phrase the 
'knowledge industry' in his pioneering book entitled The Production and Distribution of Knowledge in the United States. Later, Machlup published some other relevant works, including Knowledge and Knowledge Production (1980), The Branches of Learning (1982) and The Economics of Information and Human Capital (1984). ${ }^{2}$ His ideas have highlighted the significance of knowledge accumulation or production for economic growth in modern economies and have stimulated subsequent research into the knowledge economy. For instance, 1979 Nobel Laureate T.W. Schultz has applied Machlup's (1962) concepts of education in his important book entitled The Economic Value of Education (1963), which later became an underlying basis of the new growth theory developed by his Chicago colleague Robert Lucas in the 1980s.

\subsection{Fritz Machlup's Analysis of Knowledge Production}

Machlip's 1962 book represents the first major scholarly promulgation of the 'information revolution' and the 'knowledge society' (Langlois, 1985). According to Machlup (1962, pp. 21-22; 1980, p. 108), knowledge can be classified into the following five classes: (1) practical knowledge, ${ }^{3}$ (2) intellectual knowledge, (3) small-talk and pastime knowledge, (4) spiritual knowledge and (5) unwanted knowledge. ${ }^{4}$ In addition, Machlup (1962, 1980, Ch. 14) classified knowledge production into six major knowledge industries and branches: (1) education, (2) research and development (R\&D), (3) artistic creation and communication, (4) media of communication, (5) information services and (6) information machines. According to some preliminary estimates provided by Machlup (1962, pp. 354$357)$, total knowledge production for the USA in 1958 was $\$ 136,436$ million, with $\$ 60,194$ million in education, $\$ 10,990$ million in $\mathrm{R} \& \mathrm{D}, \$ 38,369$ million in media of communication, $\$ 8,922$ million in information machines and $\$ 17,961$ million in information services. ${ }^{5}$ The ratio of knowledge production to adjusted GNP in 1958 was almost $29 \%$.

In the 15 years after Machlup's research, Porat and Rubin (1977) took up and extended Machlup's (1962) work to complete a nine-volume report entitled The Information Economy, frequently referred to as the Commerce study. The main difference between Machlup's (1962) work and the Commerce study is that the Commerce study rigidly used the data compiled by the Bureau of Economic Analysis in the official national income accounts. For his work, Machlup (1962) took some of the activities into account that are not part of the national income accounts. According to the Commerce study, the primary information sector accounted for $25.1 \%$ of GNP in 1967 and the secondary information sector accounted for an additional $21.1 \%$ of GNP. Overall, $46.2 \%$ of US GNP could be attributed to the activities of the information sector in 1967 and the USA had become the de facto information economy. ${ }^{6}$

Rubin et al. (1986) further provided updated US statistics on the production of the knowledge industry presented by Machlup (1962) up to 1980. Their major findings indicate that total expenditures for knowledge production have steadily increased from 1958 to 1980 , rising from $\$ 138,825$ million in 1958 to $\$ 201,080$ million in 1963, \$290,809 million in 1967, \$432,261 million in 1972, \$700,971 million in 1977 
and $\$ 967,909$ million in 1980 . The knowledge industry, as a result, accounted for $28.6 \%$ of adjusted GNP in 1958 to $31.0 \%$ in $1963,33.3 \%$ in $1967,33.9 \%$ in 1972 , $34.2 \%$ in 1977 and $34.3 \%$ in 1980 .

Machlup is a defender of the neoclassical micro-theory. His investigation of knowledge and economics 'extended only to the role of knowledge as a commodity that can be bought, sold, and invested in', and his Knowledge Project is methodologically more of 'a semantic exercise than an economic analysis' (Langlois, 1985, p. 233). Clearly, Machlup's methodological position is best understood from his scholarly background, that is, the Austrian School. ${ }^{7}$ In this regard, Vaughn (1994) has pointed out that, to be part of the greater academic community, it had become necessary for eminent Austrian economists such as Fritz Machlup, Joseph Schumpeter, Oskar Morgenstern and Gottfried Haberler (who had left Austria for America during the 1920s or 1930s) to examine their Austrian themes using neoclassical language and techniques. Indeed, Machlup's 1962 work has been called 'an Austrian theme in a neoclassical setting' (Vaughn, 1994, p. 36).

\subsection{F. A. von Hayek and the Knowledge Problem}

From an Austrian perspective, one of the driving features of the market process is the fact that 'knowledge is a multifaceted, heterogeneous, disaggregated, often private or tacit and imperfect phenomenon' (Vaughn, 1994, p. 4). Historically, the Austrian exposition of the knowledge subject can be traced far back to the early work of the founder of the Austrian School, Carl Menger, in his Principles of Economics first published in 1871 (Vaughn, 1990, 1994; Langlois, 1991; Baetjer, 2000). In the 1930s and 1940s, Hayek, who would become the best known Austrian economist of the second half of the twentieth century, ${ }^{8}$ explicitly advanced one of his most significant ideas - the role of the 'division of knowledge' (which later became known as the knowledge problem) - and emphasized the importance of dispersion of knowledge and information among masses of people (Machlup, 1976, pp. 36-37).

The knowledge problem is a central topic of the Austrian analysis (Kasper and Streit, 1998, Ch. 3.1). In his 1937 paper 'Economics and Knowledge', and subsequently in his 1945 paper 'The Use of Knowledge in Society', Hayek attacked the conventional assumption of complete knowledge and stressed the nature of the economic problem:

But in our analysis, instead of showing what bits of information the different persons must possess in order to bring about that result, we fall in effect back on the assumption that everybody knows everything and so evade any real solution of the problem.... It has become customary among economists to stress only the need of knowledge of prices, apparently because - as a consequence of the confusion between objective and subjective data - the complete knowledge of the objective facts was taken for granted. (Hayek, 1937, p. 49)

The economic problem of society is thus not merely a problem of how to allocate 'given' resources - if 'given' is taken to mean given to a single mind, which 
deliberately solves the problem set by these 'data'. It is rather a problem of how to secure the best use of resources known to any of the members of society, for ends whose relative importance only these individuals know. Or, to put it briefly, it is a problem of the utilization of knowledge not given to anyone in its totality. (Hayek, 1945, pp. 519-520)

That is, Hayek recognized that the lack of (perfect) knowledge - human ignorance - is constitutional. In essence, the economic problem is concerned with how heterogeneous individuals with limited knowledge carry out their actions and execute their plans over time through exchanges with each other. The concept of competition, to Hayek, means decentralized planning by heterogeneous individuals with limited knowledge (i.e. heterogeneous individuals who possess differential knowledge). His notion of equilibrium, in this context, implies a specific situation in which all heterogeneous individuals' plans are synchronized. More importantly, the interactions of all these heterogeneous individuals (best known as the market process or a catallaxy) can lead to the creation or discovery of new knowledge.

Later, in his first volume of Law, Legislation and Liberty, Hayek integrated into his previous analyses the concept of tacit knowledge - we know more than we can tell - developed by Polanyi (1958) and stressed a new feature of the market process:

Although still an unfamiliar conception, the fact that language is often insufficient to express what the mind is fully capable of taking into account in determining action, or that we will often not be able to communicate in words what we well know how to practise, has been clearly established in many fields. (Hayek, 1973, pp. 76-77)

Thus, it is not difficult to infer that the market process is a trial-and-error process, and it is not surprising to observe that people are wrong in their decisions from time to time. Hayek himself did not further investigate the implications of tacit knowledge in market economies, but the role of knowledge has become a major theme of the Austrian analysis (Vaughn, 1994, p. 122).

In his 1974 Nobel Prize lecture, Hayek again warned that economists pretended to know what was in practice not fully known or measurable, and they inevitably risked giving false advice. He said:

To act on the belief that we possess the knowledge and the power which enable us to shape the processes of society entirely to our liking, knowledge which in fact we do not possess, is likely to make us do much harm. (Hayek, 1974)

All in all, the market is instrumental and necessary for the realization of individual freedom, the solving of economic problems and the gestation of new knowledge. The central planners and/or boards characterized by their limited knowledge cannot predict the final outcomes of individual actions in the unknown future. They cannot just issue authoritative orders to solve the economic problems existing in society. People learn by doing and acquire new knowledge through the competitive market process. The market is an institution for the coordination, exchange and utilization of the differential knowledge of individuals. From an Austrian perspective, 
the competitive market process has led to beneficial interaction among market participants.

\subsection{The Impact of Antitrust and Intellectual Property on the Competitive Market Process}

The Austrian analysis of the competitive market process consists of the following three key concepts: (1) the entrepreneurial role, (2) the role of discovery and (3) rivalrous competition (Kirzner, 1997). An Austrian perspective emphasizes that entrepreneurs can operate to 'change price/output data' and it is 'entrepreneurial boldness and imagination' that drives the market process. An entrepreneur is always ready to be surprised in an open-ended, uncertain world and also prepared to take actions to profit by such surprises. Entrepreneurs compete with other entrepreneurs and the competitive process refers to a series of discoveries generated by that 'entrepreneurial boldness and alertness' (Kirzner, 1997, pp. 70-73).

In contrast, some government-enforced policy such as antitrust regulation and intellectual property rights (IPRs) protection (such as patent rights, copyrights, semiconductor chip protection and trademark protection for the USA) might interfere with the Austrian market-process world of entrepreneurial discovery. Thus, a further investigation of the Austrian position on antitrust and intellectual property has become consequential. One might promptly anticipate a plentitude of work on the subjects of antitrust and intellectual property to be found in the Austrian literature. Surprisingly, however, the Austrian School economists have so far offered very few analyses of these aspects.

In a global society, the IPRs system has become prevalent and dominant in controlling access to knowledge, the dissemination of knowledge and also the trading of knowledge-related goods and services. ${ }^{9}$ The emergence of the intellectual property system such as a patent creates a monopoly price (or a heavy tax) on the use of knowledge. In this regard, Austrian economists have, from time to time, explained the abuse of patent data as indicators for innovation and technical change and suggested the abolition of the patent system for promoting the market process (see Oakman, 1986; Desrochers, 1998, for example).

In relation to antitrust, the following statements seem to be quite consistent with the Austrian notion of the competitive market process:

The antitrust prohibition of price discrimination, merging, price fixing, and even free-market monopolization prevents freely contracting parties who hold legitimate rights to property from making, or refusing to make, certain contractual arrangements that they believe to be in their best interests.... [P]rivate and peaceful activities such as price discrimination, merging, tying, and price fixing violate no property rights in the ordinary sense of the term; that is, they do not necessarily involve force, fraud, or misrepresentation. Yet, from a strictly natural-rights perspective, the antitrust laws themselves which regulate private and peaceful trade are inherently violative of property rights. (Armentano, 1999, pp. 99-100) 
To Austrian economists, the freedom of an individual's participation in economic activities to profit is an essential ingredient of human (private) property rights. Turning to their concern, the intervention of antitrust policy clearly decreases the market value of asset titles and substantially circumscribes private property rights.

\section{The New Growth Theory: Knowledge, Technology and Innovation as the Sources of Growth}

Although the Austrian School economists investigated the general subject of knowledge much earlier and made a significant contribution, it was a group of Chicago School economists - T.W. Schultz, Gary Becker and particularly Robert E. Lucas and Paul M. Romer ${ }^{10}$ - who technically incorporated more direct knowledge into their theories and models and promoted the research domain of growth theory to the academic frontier. Romer (1986) and Lucas (1988) initiated the research wave in the mid-1980s and the burgeoning growth literature that followed. According to the new growth theory, the advance of knowledge is a crucial determinant of long-term economic growth. The current revival of interest in growth theory, to a considerable extent, stems from a lack of good aggregate-level models to capture facts that have long been acknowledged by growth theorists (Romer, 1994).

\subsection{Background and Spillover Models}

1. There are many firms in a market economy.

2. Discoveries differ from other inputs in the sense that many people can use them at the same time.

3. It is possible to replicate physical activities.

4. Technological advances come from things that people do.

5. Many individuals and firms have market power and earn monopoly rents on discoveries.

(quoted from Romer, 1994, pp. 12-13).

Romer (1994) has argued that the neoclassical growth model developed by Solow (1956) only captured the aforementioned facts 1, 2 and 3. In both the Romer model (1986) and the Lucas model (1988), fact 4 (but not fact 5) is considered, and the technology is endogenously provided. In effect, based upon their conceptual nuances, explanations for sources of sustained growth in the new growth literature can be further divided into two major strands, that is, technological spillovers and human capital spillovers (or normally termed knowledge spillovers). ${ }^{11}$ In his model, Romer (1986) assumed that the aggregate production function could be expressed as $Y=$ $A(R) F\left(R_{i}, K_{i}, L_{i}\right)$. In this expression, $A$ denotes the public stock of knowledge that is a function of aggregate expenditure on research and development, $R$, by firms. $K_{i}$ and $L_{i}$ denote the level of capital and labour by firm $i$. Romer's breakthrough was to assume that it is (technological) spillovers from private research activities that lead to advancement in the public stock of knowledge. 
Lucas (1988) considered the external effects of human capital built on the concept of human capital developed by Schultz (1963) and Becker (1964). ${ }^{12}$ These effects are seen as spillovers from one person to another, and to some extent contribute to the productivity of all factors of production. ${ }^{13}$ Technically, his formulation of equilibrium path with external effects directly follows from Arrow (1962) and Romer (1986). ${ }^{14}$ The engine of growth in the Lucas model (1988) is human capital (spillovers). It seems that output for firm $i$ takes the form $Y_{i}=A(H) F\left(K_{i}, H_{i}\right)$, where the level of technology $A$ is a function of human capital $H$. Lucas $(1988$, p. 19) repeatedly emphasized that 'human capital accumulation is a social activity, involving groups of people in a way that has no counterpart in the accumulation of physical capital'.

\subsection{The Schumpeterian Framework}

Another line of growth inquiry points to endogenous technological change and innovation as the engine of growth (e.g. Romer, 1990; Grossman and Helpman, 1991; Aghion and Howitt, 1992). Many of the subsequent R\&D-based models in the new growth literature (and certainly some referenced above) cited Joseph Schumpeter as an inspiration. Schumpeter (1975, pp. 82-83) argued that in dealing with capitalism we are dealing with an evolutionary process .... The fundamental impulse that sets and keeps the capitalist engine in motion comes from the new consumers' goods, the new methods of production or transportation, the new markets, the new forms of industrial organization that capitalist enterprise creates ... . This process of Creative Destruction is the essential fact about capitalism.' Schumpeter emphasized that innovation is a central element of economic activity, and development propelled by innovation is an evolutionary process.

The Schumpeterian perspective on growth influenced to a great extent some recent work such as Aghion and Howitt (1998) and Nelson (1996). According to Nelson (1996, pp. 109-113), in a Schumpeterian or evolutionary context a firm has three features: its strategy, its structure and its core capabilities. A firm defines and rationalizes its objectives based on a set of broad commitments. In practice, it is formidable for a firm to actually figure out a best strategy. A firm, however, will not survive for very long if it only produces a given set of products with a given set of processes. To survive in the long run, a firm must innovate and requires a set of core capabilities in $\mathrm{R} \& \mathrm{D}$ that it can carry on. In a rapidly changing environment, firms will eventually choose somewhat different strategies, subsequently leading to development of different structures and core $(\mathrm{R} \& \mathrm{D})$ capabilities.

\subsection{Frontline Appeal and Comparative Assessment}

Romer (1986) and Lucas (1988) were the primary developers of the new growth theory and their works have generated tremendous influence in the mainstream literature. In addition to receiving numerous significant awards, Romer was also named one of America's 25 most influential people in 1997 by TIME magazine for 
his new growth theory, which, according to the magazine, might 'revolutionize the study of economics'. Lucas was awarded the 1995 Nobel Prize for his rational expectations thesis. It was even predicted that he might be awarded a second Nobel Prize because of his influential 1988 paper 'On the Mechanics of Economic Development'. ${ }^{15}$ A thoughtful investigation of the development and interpretation of the new growth theory might lead one to inquire into the following questions. Do the key elements of the new growth theory represent an intellectual breakthrough from an epistemological perspective? In addition, does any relationship exist between the Austrian analysis of knowledge and the new growth theory? It has been widely recognized that Austrian economics is almost entirely focused on microeconomics. ${ }^{16}$ Thus, in the first place one might be unaware of the nexus between the (micro) Austrian analysis of knowledge and the (macro) new growth theory. After further examination, one might find some evidence that the Austrian analysis of knowledge and the macro analysis of the new growth theory are related to some extent.

Baetjer (2000) has pointed out, from an Austrian perspective, that capital is embodied knowledge and, consequently, capital development is a social learning (and ongoing) process. The key concepts and results such as 'knowledge as the basic form of capital' (Romer, 1986, p. 1003), 'endogenous technological change' (Romer, 1990) and 'growth rates increasing over time' (Romer, 1986, p. 1002) do not differ from the Austrian analysis of knowledge. The main difference between the Austrian perspective and Romer's work centres on their distinct views on 'what factors slow these tendencies to increasing rates of growth' (Baetjer, 2000, p. 169). From an Austrian perspective, Romer $(1986,1990)$ inappropriately regarded output as an additively separable function of all the distinct types of capital goods, and failed to comprehend the process by which technological change occurs. The real challenge for exponential growth is how to maintain capital complementarities in an environment of incomplete and vastly changing knowledge.

It would appear that the Austrian predilection for market-oriented knowledge (for growth) and the mainstream analysis of knowledge-driven growth, despite their remaining disagreements and some diverse foci, are analytically compatible and sequentially connected to a great extent. ${ }^{17}$ Austrians criticize the neoclassical assumption of given knowledge and emphasize the constitutional ignorance of human existence. However, one might initiate appropriate institutional arrangements such as educational reform to ease human ignorance and facilitate the accumulation of knowledge. Over time, the accumulation of knowledge can lead to long-term economic growth.

It has become customary for new growth theorists to make simplified assumptions in order to keep their models tractable. Technically speaking, the present interpretation of the new growth theory that emphasizes the importance of knowledge to long-run growth can be viewed to some extent as the restructuring of the microfoundations of mainstream macroeconomics towards the Austrian School. In this regard, Romer (1986) and Lucas (1988) can best be understood as pioneers in constructing mathematical models of knowledge. Nevertheless, their concepts and insights are absolutely not novel if one takes a close review of the Austrian literature. 
Note, for example, that the following statements of strong Austrian flavour were actually made by Romer (1994) in his concluding remarks:

We will be able to address the most important policy questions about growth: In a developing country like the Philippines, what are the best institutional arrangements for gaining access to the knowledge that already exists in the rest of the world? In a country like the United States, what are the best institutional arrangements for encouraging the production and use of new knowledge? (Romer, 1994, p. 21)

A special note on Schumpeter seems to be necessary for completing the analysis in this section. If Schumpeter is counted as an Austrian economist, the overall Austrian insights into economic growth will become more significant. Schumpeter's academic lineage, however, is not unambiguous. Although he is frequently regarded as an economist in the Austrian School tradition (see Ekelund and Hébert, 1997, Ch. 20, for example), others such as Landreth and Colander (1994, pp. 390-391) classify Schumpeter as a quasi-institutionalist. Due to his renowned emphasis on the 'evolutionary process' of capitalist development, perhaps it is better to recognize Schumpeter as one of the early founders for creating new work in 'evolutionary economics'. ${ }^{18}$

\section{The Growth of Income and Wealth Inequality}

\subsection{The Lacunae of the Growth-oriented Knowledge Economy}

Although we now live in a knowledge economy, this economy has also brought an increase in income inequality (Atkinson and Court, 1998; Thurow, 1999). ${ }^{19}$ According to the evidence shown in the US Census Bureau's Historical Income Inequality Tables ${ }^{20}$ inequality in household income in the USA has been significantly on the rise over the past two decades. The Gini coefficients remained at the $0.39-0.40$ level from 1967 to 1981 . Then, the coefficients increased from 0.41 in the early 1980 s to 0.43 in the early 1990 s, to 0.45 in the mid-1990s, and to 0.46 since 2000 . Keister's (2000) study has further pointed out that wealth is much more unequally distributed than income in the USA. In 1989, the share of the top $1 \%$ of income recipients was about $16 \%$ of all income. In contrast, the wealthiest $1 \%$ of all households owned $39 \%$ of all assets. Barlett and Steele (1994) have shown that the USA is a two-tax, two-class society. More and more in taxes are being paid by the middleincome taxpayers, while less and less in taxes are being paid by corporations. The wealthiest individuals frequently take advantage of generous write-off provisions. US politicians, especially congressmen, have, according to Barlett and Steele (1994), championed and reinforced the arguments for tax cuts to benefit the wealthy at the expense of the middle class.

In fact, it is a class war that 'Middle America' has lost, and several studies have examined the decline of the US middle class. Newman $(1988,1993)$ conducted in-depth interviews with ordinary Americans mainly to explore the socioeconomic characteristics of the middle class. She clearly found that the American middle 
class was facing the bitter problem of downward mobility (i.e. the gradual loss of decent jobs and a reliable income). Strobel (1993) also argued that, due to the general economic decline, the American middle class had been under tremendous living pressure. Peterson (1994) pointed out that the shrinking of the middle class in the 1980s was a major consequence of the USA's silent depression that had been ongoing. Strobel and Peterson (1997) further explained that the shrinking size of the American middle class was due to lower real wages, lost middle-class jobs and increased financial burdens. Unfortunately also for the poor, Galbraith (1992) pointed out that the underclass (the working and non-working poor) exhibited a lower voter turnout and had handed over the control of government to the 'contented', that is, the more financially secure group.

Tachibanaki (2006) examined inequality and poverty in Japan and warned that Japan had entered a critical period. The degree of inequality had been increasing, and its level had also become one of the highest among advanced industrialized countries. Burniaux et al. (1998) studied 13 OECD countries and found that inequality (measured in disposable income) had risen in most of them between the mid-1970s and the mid-1990s. ${ }^{21}$ Indeed, growing inequality has become a global phenomenon not confined to the OECD countries. For China, the benefits of growth have been primarily absorbed by urban areas and the coast, and income distribution has become increasingly unequal since economic reforms were initiated in 1978 (World Bank, 1997). According to the United Nations (2005) Report on the World Social Situation, $80 \%$ of the world's GDP belongs to the 1 billion people living in the developed countries, while the 5 billion people living in developing countries share the remaining 20\%. Their analysis of the reliable World Income Inequality Database, with a sample of 73 countries, further indicates that within-country income inequality rose in 48 countries (approximately two-thirds) between the 1950s and the 1990s. Overall, the prospect of meeting global commitments to reducing inequality, as outlined in the 1995 World Summit for Social Development in Copenhagen and endorsed in the United Nations Millennium Declaration, is bleak.

\subsection{The Insights of Professors Gunnar Myrdal and Kenneth E. Boulding}

Gunnar Myrdal, a 1974 Nobel Laureate and a well-known institutionalist, investigated the South Asia region (including Pakistan, India, Indonesia, Burma, the Philippines, Thailand, Ceylon and Malaya, and occasionally South Vietnam, Cambodia and Laos as well) and published a three-volume book entitled Asian Drama: An Inquiry into the Poverty of Nations in 1968. To pursue the goal of a sustainable society, some of his penetrating insights of almost five decades ago deserve further attention. The entire third volume of Asian Drama, Problems of Population Quality, was devoted to the study of health, education and the social system as a whole, with an application of his analysis to government action.

From a holistic perspective, a social system in each South Asian country is composed of a large number of conditions that can be classified into the following six broad categories: (1) output and incomes, (2) conditions of production, (3) levels of living, (4) attitudes towards life and work, (5) institutions and (6) policies (Myrdal, 
1968, pp. 1859-1864). The first three categories represent 'economic factors', and categories 4 and 5 represent 'non-economic factors'. Category 6 is a mixture and can be considered to belong to the 'economic factors' when the purpose of the policies is to induce changes in the first three conditions. In a social system, all the aforementioned conditions are causally interrelated and economic conditions do not have precedence over the others.

Myrdal, for instance, pointed out that the South Asian people have not only been insufficiently educated but have also been miseducated to a great extent (due to their past colonial rule). Thus, educational reforms needed in these now independent countries are far more than the popular suggestion of increased 'investment in education'. The main reason is that 'existing educational establishments are part of a larger institutional system, which includes social stratification; and this system is supported by people's attitudes, which themselves have been moulded by the institutions' (Myrdal, 1968, p. 1649). Influential vested interests in these countries have been embedded in the educational and institutional systems, and they resist or warp reform policies.

To Myrdal (1974, p. 729), development means 'the upward movement of the entire social system'. Unfortunately, 'development was commonly understood as simple economic growth, regularly accounted for in terms of very questionable statistics on gross national product or income .... What the poor do need are radical institutional reforms' (Myrdal, 1978, p. 782). Kenneth E. Boulding, a late AEA president and also a well-known institutionalist, notes on this point:

One area where economists have a good deal to be humble about is in the field of economic development of the poor countries. In the rich countries we have done fairly well; in the poor countries our record is distinctly spotty. (Boulding, 1966, p. 11)

It is well known that the burden of poverty has fallen heavily on women and children. This phenomenon is particularly significant for developing countries. In particular, people in poverty, due to their more limited access to health care and services, exhibit a worse health status (OECD, 2003; WHO, 2006). Indeed, poverty has become a chronic phenomenon and can be better understood only from a broad institutional perspective. Poverty, for instance, is frequently entangled with phenomena such as contagious diseases and criminal activities, ${ }^{22}$ which cause a great negative impact on other individuals and communities. Thus, reducing poverty is essential for achieving a sustainable community if poverty reduction induces greater public health and security. From a global perspective, the reduction of poverty is even more significant if it contributes to disease eradication and global peace, both of which are crucial for global sustainability. ${ }^{23}$

\section{An Assessment of Austrian and Mainstream Views}

Landreth and Colander (1994, p. 407) have pointed out that it remains difficult to find an Austrian who is not a conservative; most simply assume the market is desirable and necessary for achievement of individual freedom'. ${ }^{24}$ Obviously, 
the Austrian analysis of the market-oriented knowledge is far from perfect and one might simply present the Austrians with two basic questions. First, it is not a problem to admit that people are to some extent ignorant. However, why do people possess differential knowledge? In other words, why does the Austrian School regard individuals with differential knowledge as a given in their analysis? It is clear that the Austrian analysis methodologically rationalizes the existing heterogeneous knowledge structure of the capitalist system. It is not difficult to imagine, however, that the profits or losses from market activities and, accordingly, the distribution of income and wealth of the society are closely related to the differential knowledge of economic agents. Since differential knowledge is a key element in deciding market winners and losers, the study of the formation of the knowledge structure for market participants is vital. The Austrian analysis, however, takes the existing heterogeneous knowledge structure of society for granted without further examination of its causes and far-reaching consequences. Not surprisingly, the discovery and production of knowledge are greatly extolled, but the coexistent phenomena such as growing income inequality have been reduced to triviality in the Austrian analysis.

Second, why does the implementation of free market institutions cater to all the interests of differential people and communities? In his analysis of the Austrian and Chicago schools, Hunt (1992, pp. 572-584) has shown that these two schools purport to be a value-free science and claim that their theory fits all people at all times. In contrast, institutionalists who consider their economic discipline to be the original institutional economics (OIE) or economists greatly influenced by the OIE have emphasized a value commitment to study economics (cf. Myrdal, 1958, 1981; Boulding, 1969; Söderbaum, 1999). ${ }^{25}$ Myrdal, for instance, overtly remarked:

Valuations are always with us. Disinterested research there has never been and can never be. Before we can have answers there must be questions. There can be no view except from a viewpoint. In the questions raised and the viewpoint chosen, valuations are implied. (Myrdal, 1981, p. 44)

Indeed, the choice of a free market along with its institutions is merely an option and the paramount propaganda of the free market structure unleashed by the Austrians remains dubious. Differential people and communities should have wide latitude in choosing and building economic institutions catering to their specific interests such as pursuing economic equality for social justice or developing a selfreliant type of economy with limited external trade, and so on. The concept of economic freedom should be expanded not only to include the concept of free market competition but also to incorporate the choice of other economic institutions created for satisfying different groups of people.

The limitations imposed by the mainstream's narrow analysis of the knowledge economy are also evident. Knowledge is largely regarded as the central impetus to economic growth. Yet one might ask the following question: Can knowledge be regarded as the central element for promoting socioeconomic progress such as creating a sustainable society? As soon as this type of question is asked, some critical issues emerge. For example, many poor people relentlessly die of hunger or disease every day. According to the United Nations 2005 Report on the World Social 
Situation, the wealthiest $20 \%$ on earth occupy $86 \%$ of all private consumption, while the poorest enjoy just above $1 \%$. The pressing issue, indeed, is not to produce more but to seek a knowledgeable allocation and distribution (to alleviate poverty).

Moreover, the mainstream underlying emphasis on the competitiveness of a single person or country is very shortsighted, which will not fulfil the goal of long-term development of humans. ${ }^{26}$ From a global perspective, we can intuitively consider that there exists only one human society on earth. It can be fairly understood that our human society will not develop for very long if competition exists between different generations. As an older generation controls the society, it will not allocate enough resources to enhance the competitiveness of the younger generation. The younger generation, as a result, will become weaker over time and the society as a whole will eventually come to an end. ${ }^{27}$ Thus, the concept of competition (or competitiveness) is de facto insufficient for dealing with the nature of long-term development of human societies.

\section{The Evolution of Knowledge: Knowledge and Human Development}

Human life is collective, cumulative and evolutionary in character. It is reasonable to state that an ordinary individual living in the twenty-first century may not be any more clever than a person living in the first century. Many well-known facts can immediately justify this statement. Just take the phenomenal Egyptian pyramids for example. So far, modern scientists have not figured out exactly how they were built. However, we realize that the average person lives better and longer nowadays. Why? The truth is that knowledge has accumulated over time and spread from generation to generation. That is, the knowledge fund has grown and modern people have consequently been endowed with greater intellectual capacity and capital. To better understand this point, we might hypothetically imagine the existence of $a$ knowledge barn (or commons) for human society from an overlapping-generations perspective. In primitive and ancient times, the knowledge barn only accommodated a small quantity of knowledge. When our human ancestors went into the knowledge barn, they found few pieces of knowledge available for use. As time went on, more pieces of knowledge were piled up in the barn as each human generation made its marginal contribution to the accumulation and spread of knowledge. Thus, the existing generations have to recognize that they are very fortunate. Knowledge has accumulated and spread across the world generation by generation. This longterm process of gestation to some extent benefits all of us.

Let us consider a very basic (but important) piece of knowledge. That is, one plus one equals two $(1+1=2)$. In relation to this simple piece of knowledge, the various kinds of symbols $(1,2,+,=)$ and the addition rule were previously designed and created by our human ancestors. This piece of knowledge is their legacy and is collectively inherited by all of us. We can easily understand that accountants could not do bookkeeping without it. Without it, Bill Gates's programmers would not be able to write computer programs and help Bill Gates establish his Microsoft empire. In fact, astronauts would not have landed on the moon without this piece 


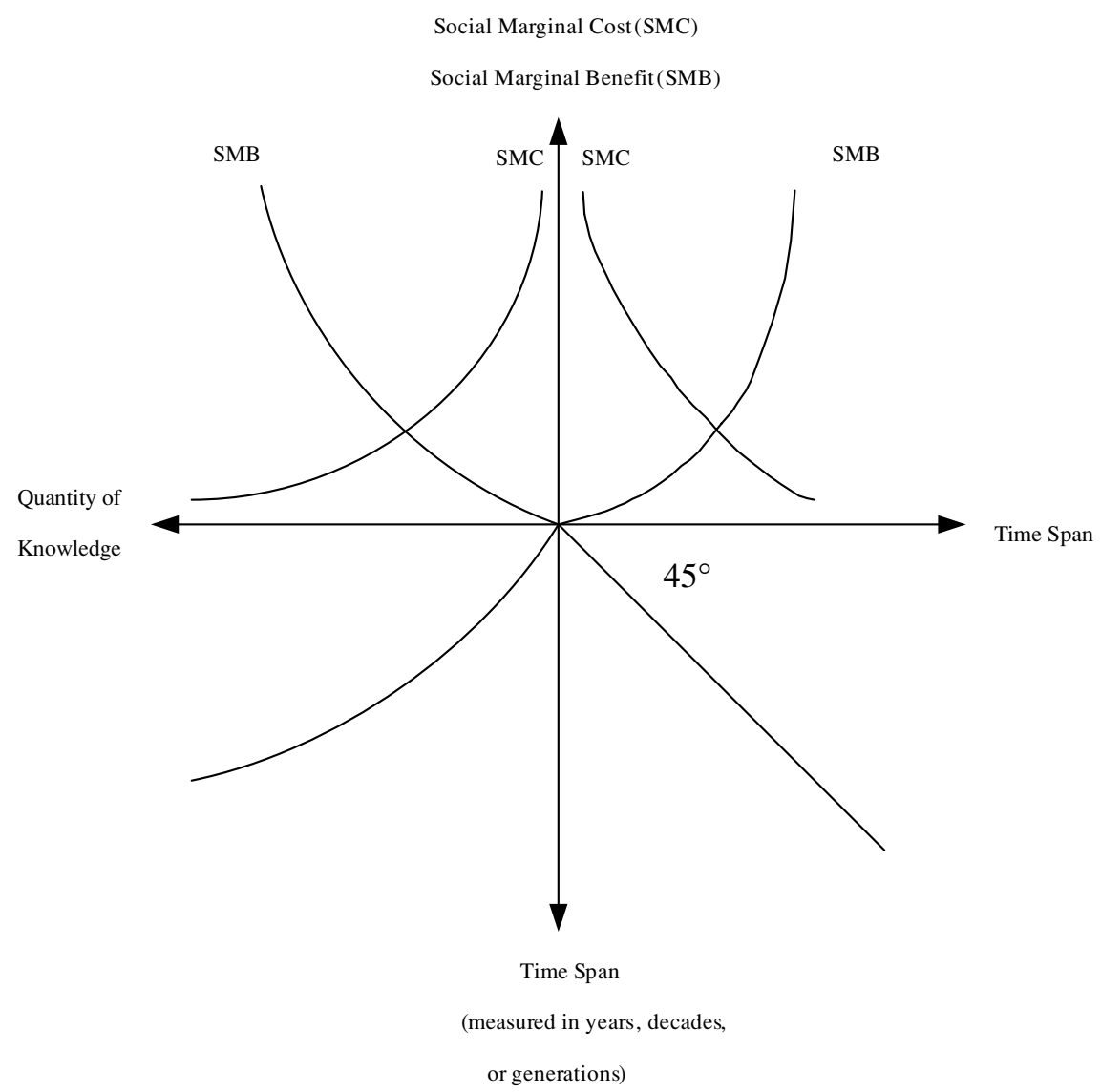

Figure 1. The Evolution of Knowledge.

of knowledge. As a matter of fact, a pure inventor or creator does not exist from an intellectual sense.

It is also known that $R \& D$ activities are central to the generation of new knowledge. R\&D activities are dispersed across individual workrooms, private profit and non-profit organizations, academic institutions and governmental agencies. If one wants to measure, for example, the total cost of R\&D activities, one has to take the monetary and non-monetary outlays of the parties involved into account. Thus, it can be expected that the costs to society as a whole will be extraordinarily high at first. The benefits that society can derive from the enormous amounts of money, time and effort expended on R\&D activities are normally low in the initial stages, but are expected to increase over the long run. This phenomenon is particularly significant for basic research.

Figure 1 summarizes the aforementioned arguments and shows the evolution of knowledge from a long-term perspective. ${ }^{28}$ The bottom left-hand quadrant shows that 
knowledge accumulates and spreads from generation to generation over time; the basic unit of the time span, depending on different types of knowledge (for further analyses), can be measured or denoted in terms of years, decades or generations. From an overlapping-generations perspective, the top two quadrants show that, corresponding to each generation, the social marginal costs decrease and the social marginal benefits increase as the quantity of knowledge accumulates.

Each human generation enjoys the benefits of knowledge transmitted from the preceding generations and, consequently, passes the accumulated benefits (i.e. the preceding benefits plus the marginal benefits created by the existing generation) to the immediate subsequent generation. In this respect, one might be aware that knowledge is a special type of international public good. An international public good, in principle, can benefit all countries, all people and all generations. Although each human generation is mortal, its knowledge exists and continues to expand in society. That is, the collective knowledge is still living and is vital to the long-term development of humans.

\section{The Conventional Wisdom: Indigenous Knowledge}

The efforts to comprehend the importance of knowledge are by no means limited to economists. The recognition of and emphasis on indigenous knowledge has been intensified by recent developments in environmentalism and feminism (Jacobs, 1994). Indigenous knowledge usually refers to unwritten knowledge preserved locally in oral traditions. Such knowledge is seen to be particularly abundant in the knowledge of the environment or nature and has been increasingly recognized as critical for sustainable development (e.g. Brokensha et al., 1980; Gadgil et al., 1993; Ellen et al., 2000; Fernando, 2003). Take two of Taiwan's indigenous groups, the Thao and Tsou, for example. The Thao are Taiwan's smallest ethnic group, with a population of about 300 people who live in the surrounding area of Sun Moon Lake. The Tsou population is approximately 6000 to 7000 people, most of them living in the Alishan area. The Thao people, for example, have developed very delicate techniques in catching kiluat, a specific kind of lake fish, on waterweeds of Sun Moon Lake. The Tsou people, for example, have successfully furthered the first grassroots ecological park called Tanayiku in the Alishan area. Alishan and Sun Moon Lake are two of the most famous scenic areas in Taiwan. Without the conventional wisdom of the Thao and Tsou, the natural environment of Sun Moon Lake and Alishan could not have been well preserved until today.

A central argument is that sustainable development must be embedded in indigenous knowledge systems, and ignorance of the systems will certainly lead to failure in development. Weatherford (1994) argued that indigenous people may be the only people capable of salvaging modern civilization. As indigenous people have gradually lost their cultural identities, we are actually losing indigenous knowledge, our connections to the past, and jeopardizing our future. According to Semali and Kincheloe (1999, p. 3), indigenous knowledge 'reflects the dynamic way in which the residents of an area have come to understand themselves in relation to their 
natural environment and how they organize that folk knowledge of flora and fauna, cultural beliefs, and history to enhance their lives'.

The following is another real example of indigenous knowledge. The Onge people make up an aboriginal tribe with a population of less than 100 people. They live on Little Andaman Island (India) in the Bay of Bengal. They possess indigenous knowledge encompassing medicine, biology and nature (Norchi, 2000). They rely on their knowledge of a specific plant to treat fever and gastrointestinal disorders. This same plant is also effective in dealing with malaria and, consequently, the Onge people no longer suffer from that disease. Now, scientists have been conducting tests on the medicinal plants used by the Onge people, and pharmaceutical companies have also shown an interest in reaching an agreement with the patentee. In addition, all 96 Onge people survived the tsunami in December, 2004, which left around 300,000 people missing or dead in or around the Indian Ocean, including residents of the Onge people's nearby town of Hut Bay. Before the tsunami, the Onge people fled into the jungle for protection after they found that the water in the creek had suddenly run out to sea.

The work of protecting and promoting indigenous knowledge, however, is challenging. The following urgent issues need to be examined and evaluated. First, it is important to conduct research on how people can preserve the natural environment of the indigenous people, since indigenous knowledge and their natural habitats go hand in hand. Second, whether the existing IPRs system can be applied or extended to indigenous knowledge remains highly controversial (Marinova and Raven, 2006). In this regard, Darrell A. Posey, an influential figure for his advocacy of the rights of the indigenous people, emphasized that the development of traditional resource rights (TRRs) can protect the interests of indigenous peoples and strengthen the practice of their self-determination (Plenderleith, 2004, Ch. 14). Third, a unique institutional system for the advancement of indigenous knowledge needs to be developed. The US Tribal Colleges were created in the late 1960s and the early 1970s in response to the higher education needs of American Indians. There are currently over 30 Tribal Colleges located in Indian reservations around the USA. The Tribal Colleges are different from standard community colleges or mainstream four-year colleges due to their cultural identities, and are relatively involved in a broad range of community services - including education, counselling and economic development initiatives that are specifically focused on communities that would otherwise be isolated from such resources. So far, the Tribal Colleges have not drawn enough attention from either academia or the general public, and have been persistently under financial pressure.

\section{John Stuart Mill and the Stationary State}

Now it is time to seriously reconsider the knowledge issue from the perspective of our position in human history. Boulding describes the epistemological problem as follows:

There are, of course, a number of epistemological questions, some of which lie more in the province of the philosopher than they do the economist or the social 
scientist. The one with which I am particularly concerned here is that of the role of knowledge in social systems, both as a product of the past and as a determinant of the future. (Boulding, 1966, p. 1)

What is the role of knowledge in human development? Knowledge is critical not only to economic growth but also to our society's long-term development. In light of this, what does a sustainable society look like? Following Myrdal's erudition, sustainable development of a society could be portrayed as a sustainable upward movement of the entire social system. At the very least, the current growth-oriented exposition of the knowledge economy in mainstream literature is not only monistic but also partial, which will not fulfil the goal of sustainable development. In this respect, John Stuart Mill's concept of the stationary state outlined in his Principles of Political Economy (first published in 1848) is compatible with contemporary analysis of a sustainable society and is worth further review.

Daly $(1973,1977,2005)$ traced his exposition of a sustainable economy, a steadystate economy (SSE), back to Mill's notion of the stationary state. The SSE is a physical concept that refers to an economy whose scale (i.e. resource throughput, equal to population multiplied by per capita resource use) remains at a constant level. This level neither depletes the materials from the environment beyond its regenerative capacity nor pollutes the environment beyond its absorptive capacity. Indeed, Daly's concept of SSE has not been void of practice. Most indigenous tribes organized as a closed group with a common property have practised SSE for (tens of) thousands of years on earth. O'Connor (1997) investigated Mill's concepts of a private property-based liberal society as well as a stationary-state society, and argued that the writings of Mill represent a prototype for ideals of a 'sustainable development'.

Lin (2006) also stated that Mill's concept of the stationary state is conceptually consistent with the modern exposition of sustainable development. It can be widely observed that the rich communities (nations) have tended to waste resources, whereas the poor communities (nations) have tended to destroy resources. Due to a rising inequality of wealth all over the world and limited resources on earth, the global community has become less and less sustainable. To maintain a sustainable society with an efficient use of resources, it is necessary to achieve a more equitable distribution of wealth. Although greatly influenced by David Ricardo, Mill's stationary state was not the dismal scenario that Ricardo visualized. Mill took a different view of his desirable society and outlined his desires for a good future. In his chapter on the stationary state, in which he discussed the long-run tendencies of the economy, he said:

But the best state for human nature is that in which, while no one is poor, no one desires to be richer, nor has any reason to fear being thrust back by the efforts of others to push themselves forward.... There would be as much scope as ever for all kinds of mental culture, and moral and social progress; as much room for improving the Art of Living, and much more likelihood of its being improved, when minds ceased to be engrossed by the art of getting on. (Mill, 1965, pp. 748-751) 
Looking at the economic and social conditions of his time, Mill felt that the mass of society was bypassed by the materialistic development of the Industrial Revolution and wondered whether a country with a growing economy was a desirable living place. He envisioned that the stationary state would result in an improvement in the art of living:

It is only in the backward countries of the world that increased production is still an important object: in those most advanced, what is economically needed is a better distribution... . On the other hand, we may suppose this better distribution of property attained, by the joint effect of the prudence and frugality of individuals, and of a system of legislation favouring equality of fortunes, so far as is consistent with the just claim of the individual to the fruits, whether great or small, of his or her own industry. (Mill, 1965, p. 749)

As this passage suggests, Mill's stationary state might be narrowly interpreted as a society with no (or limited) growth in physical output. Alternatively, it should be best understood as a society with unlimited growth in mental culture and improvements in economic equality (by means of wealth redistribution). In this regard, Mill's concept of the stationary state is in line with contemporary analysis of a sustainable society and is very close to the ethical-utopian perspective on sustainable development. According to van den Bergh (1996, p. 59), the ethical-utopian perspective emphasizes 'new individual value systems (respect for nature and future generations, basic needs fulfilment) and new social objectives (steady state); .. long-run policy based on changing values and encouraging citizens (altruistic) behavior as opposed to individual (egoistic) behavior'.

Surely, the transition from a growth-oriented economy towards Mill's stationary state, a final stage of civilization, will not be an easy task. Mill's vision was far, far ahead of his time. Eighty-two years later, Mill's sanity was echoed by his great fellow British economist, John Maynard Keynes. It seemed untimely, as the Great Depression was under way, that Keynes envisaged the future of our economic progress in his short essay, Economic Possibilities for Our Grandchildren. ${ }^{29}$ In 1930, looking into the future, Keynes discerned the following state of affairs:

There are changes in other spheres too which we must expect to come. When the accumulation of wealth is no longer of high social importance, there will be great changes in the code of morals.... Of course there will still be many people with intense, unsatisfied purposiveness who will blindly pursue wealth unless they can find some plausible substitute. But the rest of us will no longer be under any obligation to applaud and encourage them. (Keynes, 1963, pp. 369370)

Keynes concluded that the time for our destiny of economic bliss had not yet come, because 'avarice and usury and precaution must be our gods for a little longer still' (Keynes, 1963, p. 372). However, he encouraged mankind to change gradually and to make preparations for our destiny. 


\section{A Value-committed Vision of the Knowledge Economy: An Emancipation of the Growth-oriented Capitalist Society}

\subsection{Promoting Green Politics for Sustainable Development}

Winch (2004, p. 111) points out that Mill is one of the earliest green thinkers, whose 'defense of a zero-growth society conveys the substance of his environmentalist concerns'. Mill's virtuous stationary-state (zero-growth) society, according to Winch (2004, p. 122), is 'a continuous state of dynamic equilibrium' in which all improvements in new technologies can be redirected towards redistribution of wealth and the promotion of life quality. Do there exist any possibilities of developing Mill's high-minded mental culture (and Keynes's vision of economic bliss)? In the first place, we had better rid ourselves of growth mania. This is a formidable task and requires abandonment of the dominant emphasis on economic growth. ${ }^{30}$ Take the USA for example. Typical middle-class Americans now do have significantly higher physical products (than their counterparts living in the affluent 1950s and 1960s) but few realize that 'the more we achieve at this point yields us little in the way of enduring satisfaction' (Wachtel, 1998, p. 264). ${ }^{31}$ To achieve the goal of a sustainable society, Harris (2000) suggests that it is necessary to develop new and more democratized avenues to the formulation of values, beliefs and knowledge. Fortunately, many people and groups worldwide such as green consumption activists have taken steps to steer people's attitudes and behaviours towards a sustainable future. ${ }^{32}$

Green politics is a lively mobilization of a variety of ideas, values and reform proposals for promoting environmental conservation, civic engagement, peace and social justice, and leading socioeconomic progress to a state of sustainable development (Lin, 2008b). In principle, the development of green politics is ecologically based and shares a common concern for environmental justice and equity and has been seen as forward-looking movements for resolving deficiencies of traditional democracy. Green politics has been in gestation for many years in most Western societies and has gained some political success through organizing green parties, especially in the European countries. However, the emergence of green politics is in no way of purely political significance (for promoting green parties). Instead, it could also substantially enrich the public debate on pressing environmental issues (such as climate change and global warming), help us to better understand the relationship between economic growth and the environment and help to advise the government to implement forward-looking environmental policies.

Nearly all green activists have not merely questioned material consumption of modern societies, but also overtly addressed spiritual or metaphysical issues to steer people's attitudes and values towards new social objectives. In May 1972, the world's first national-level green party, the Values Party, was launched at Victoria University of Wellington, New Zealand. For instance, the Values Party's 1972 manifesto claimed that 'New Zealand's peculiar malady is not physical poverty; it is spiritual poverty' (Rainbow, 1993, p. 25). Founded in Coventry in 1973 as the 'People' or, as it was later known, the Ecology Party, the British green party is amongst the oldest in 
Europe. The British Ecology Party stresses that the values of conventional politics are fundamentally flawed and has created the first edition of a Manifesto for a Sustainable Society.

It might be stressed here that the USA was the world's environmental policy leader in the 1970s. The USA established a national environmental protection agency (EPA) in 1970 and passed landmark legislation on clean air and water in subsequent years. Over the past decade, citizens living outside the USA, however, have become more aware of the growing discrepancies in the attitude of the US government towards trade and the environment. On the one hand, the US government has shown aggressive leadership in promoting trade liberalization and free trade agreements. On the other hand, it has expressed persistent unwillingness to make an international commitment to environmental protection. The Kyoto Protocol came into force on 16 February 2005 with a total of more than 160 countries having ratified the agreement. The two major countries currently opposed to the Kyoto agreement are the USA and Australia. ${ }^{33}$ Many environmentalists outside the United States 'bemoan the inability of America's environmental movement to sway its own government' (Conca, 2001, p. 32).

\subsection{Developing Academic Pluralism for Sustainable Development}

In his book, Development Betrayed: The End of Progress and a Coevolutionary Revisioning of the Future, Norgaard (1994, p. 62) identified 'atomism, mechanism, universalism, objectivism, and monism' as the dominant philosophical roots of Western modernism, and noted that development had been betrayed by each of these tenets. The prevalence of the aforementioned philosophical premises has caused the exclusion of other metaphysical and epistemological premises that are better for comprehending the degradation of environmental systems and more conducive to cultural diversity. Norgaard (1994, p. 73) argued forcefully that, by publicly agreeing to monism, we not only give up a public basis for using the knowledge of other cultures, but also arbitrarily throw out answers that might be just as good and reliable.

As early as the 1970s, two influential green writings challenged mainstream economics and greatly inspired subsequent green economists. In 1972, The Limits to Growth report warned that our earth's carrying capacity would be exceeded within 100 years if the present growth trends in population, pollution, production and resource use persisted (Meadows et al., 1972). Then, in his low-frequency, wellremembered Small is Beautiful, E.F. Schumacher suggested, for example, a return to ecologically sound agricultural techniques and communal ownership for a better society, and challenged mainstream economics:

Economists themselves, like most specialists, normally suffer from a kind of metaphysical blindness, assuming that theirs is a science of absolute and invariable truths, without any presuppositions.... Buddhist economics must be very different from the economics of modern materialism, since the Buddhist sees the essence of civilisation not in a multiplication of wants but in the purification of human character... A Buddhist economist would consider ... consumption merely a 
means to human well-being, the aim should be to obtain the maximum of wellbeing with the minimum of consumption. (Schumacher, 1973, Ch. 4)

Three decades ago, Nicholas Georgescu-Roegen, a pioneer in the field of ecological economics and a lone maverick in his day, advocated the abandonment of two pillars of mainstream economics, discounting the future and maximizing utility, and pessimistically uttered that, with regard to future generations, 'our policy toward natural resources must seek to minimize regrets' (Georgescu-Roegen, 1977, p. 375). Emerging as a dismal green economist, Georgescu-Roegen's intellectual inquiry has inspired economists to some extent. Indeed, many economics students have not been merely insufficiently educated; they have been miseducated on a huge scale (see, for example, the Post-Autistic Economics Network). Undoubtedly, more and more academics will join the green movements to take their shared responsibility for the earth. The latest emergence of green economics is a promising sign of such concerns and endeavours (Lawson, 2006; Wall, 2006).

More importantly, the narrow academic circles must be expanded to consider the significance of indigenous knowledge to advance the global knowledge commons (Dei et al., 2000). The global village on earth is composed of numerous (but finite) knowledge economies. The scope or dimension of each economy can range from a small community of a country (such as the Onge people of India) to a regional integration of many countries (such as the European Union). To expand the global knowledge commons, we have to fully acknowledge and protect the characteristics of each unique knowledge system (such as indigenous knowledge possessed by a small tribe), and then help each knowledge commons develop into a specific set of economic institutions that interact with each other in a global environment. That is, each knowledge economy is best developed based upon its characteristics that are distinct from others. Once knowledge prevails in a global society, each community (whether a small tribe or a regional integration) can improve its own development by absorbing knowledge from the global commons. In addition, it can expand the global commons by injecting knowledge into it. Gradually, this process will contribute to the emergence of new economic institutions compatible with the long-term development goals of each community (such as developing a self-reliant economy with limited external trade or pursuing economic equality for social justice), and lead to sustainable development in a global environment.

\section{Conclusions}

This paper has shown that the unifaceted exposition of the knowledge economy from the perspective of increased production and accumulation has been far from perfect and cannot fulfil our goal of a sustainable future. Both the Austrian analysis of the knowledge subject and the mainstream exposition of the knowledge economy have been grounded on the concept of market competition and purported to be value-free. This paper emphasizes that the conventional concept of competition is insufficient for promoting the long-term development of human societies, and proposes that the concept of economic freedom should be expanded to incorporate the choice of 
other economic institutions (more than free market institutions) created for satisfying different groups of people.

Global sustainability is a de facto shared responsibility of overlapping generations. Fundamental to this holistic perspective is the recognition that human generations are interrelated and ought to be examined as an integrated whole. One can easily observe that the global community has become less and less sustainable due to rising economic inequality and environmental degradation. To maintain a sustainable society with an efficient use of resources, it is necessary to achieve a more equitable distribution of wealth. In this regard, this paper has argued that the notion of sustainable development has in its roots John Stuart Mill's stationary state, a valuedriven vision of a good future. Mill is one of the earliest green thinkers and his stationary state is an ideal society with an emphasis on unlimited growth in mental culture and improvements in economic equality (by means of wealth redistribution), a vision that is in line with contemporary analysis of a sustainable society.

This paper also stresses the significance of indigenous knowledge for promoting a sustainable society. Indigenous knowledge is seen to be particularly abundant in the knowledge of the natural environment and is critically important to the sustainable use of resources and balanced development. Thus, it is preferable to recognize that our earth is composed of numerous knowledge economies. In this perspective, each knowledge economy is best developed based upon its characteristics that are distinct from others. To help emancipate the current growth-oriented capitalist society and lead socioeconomic progress to a state of global sustainability, this paper concludes that we have to take active participation in promoting green politics to steer peoples' values towards new social objectives and in developing academic pluralism to advance the global knowledge commons.

\section{Acknowledgements}

This paper is an enhanced and extended version of three of my articles: 'A Sustainable Perspective on the Knowledge Economy: A Critique of Austrian and Mainstream Views', 'Human Capital and Knowledge' and 'Green Politics'. The research leading to this paper has been primarily financed by the US Fulbright program and conducted under the auspices of Augustana College, South Dakota. Earlier versions of this paper were presented at a seminar in the Department of Agricultural Economics at Michigan State University on 16 June 2005, in the US Society for Ecological Economics (USSEE) Third Biennial Conference in Tacoma, Washington, 20-23 July 2005, and at the European Association for Evolutionary Political Economy (EAEPE) 17th Annual Conference in Bremen, Germany, 10-12 November 2005. The author would especially like to thank Donald George and anonymous reviewers for their helpful comments and suggestions.

\section{Notes}

1. In the economics literature, 'human capital' and 'knowledge' are frequently used interchangeably and broadly refer to people's acquired or innate abilities that are conducive to productivity and economic growth. An embryonic emphasis on human capital or knowledge can be seen as far back to the early works of Adam Smith and David Ricardo (Kurz, 1997; Nerdrum, 1999, pp. 15-19). See Lin (2008a) for an encyclopaedic examination of human capital and knowledge. 
2. Machlup died on 30 January 1983 and did not finish his monumental inquiry, the Knowledge Project (which as planned was to cover 10 volumes).

3. Practical knowledge can be further subdivided into six types: (1) professional knowledge, (2) business knowledge, (3) workman's knowledge, (4) political knowledge, (5) household knowledge and (6) other practical knowledge.

4. Unwanted knowledge is not related to a person's interests. It is acquired by chance and retained purposelessly.

5. The data for the information services were incomplete.

6. The term 'information economy' has been occasionally recognized as a synonym for 'knowledge economy'. However, it conveys relatively limited content and primarily refers to the importance of information and communication technology for economic growth. For the latest studies of the information economy, see OECD (2002) and Varian et al. (2004). For a critical review of the historical development and progress of the information economy, see Babe (1994) and Lamberton (1994).

7. Landreth and Colander (1994, Ch. 14) have identified five groups of American heterodox economic schools based on political viewpoints that range from liberal to conservative, namely, the Radicals, Institutionalists, Post-Keynesians, Public Choice Advocates and Neo-Austrians (or simply the Austrian School). Important economists in the Austrian School include Ludwig von Mises, Friedrich Hayek, and their students Murray Rothbard, Israel Kirzner and Ludwig Lachman.

8. For a thorough review of Hayek's intellectual journey and work, see Caldwell (2004).

9. In recent years, the ideas of IPRs and the enforcement of trade-related aspects of intellectual property rights (TRIPS), which integrated IPRs into global trade, have attracted increased attention and debate. Proponents of the IPRs, on the one hand, believe that the current system not only can protect the process of invention and innovation but can also provide economic incentives for creative activities. Opponents, on the other hand, generally hold the view that the protection of IPRs has been implemented at the expense of the public knowledge domain. Richards (2002) examines justificatory arguments in defence of IPRs based on the philosophical writings of Locke, Hegel and Bentham, and finds that their defences for private property rights do not hold up well when applied to intellectual property. Boldrin and Levine (2002) think that intellectual property might be better referred to as 'intellectual monopoly' and argue that the extent of current copyrights has been excessive. See also Lessig (2001) for a similar conclusion. Hui and Png (2002) studied the impact of a change in the US copyright law in 1998 in relation to movie production and found that the Sonny Bono Act has only had a small impact on new creative activity.

10. Romer is currently teaching at Stanford University. He obtained his doctorate from the University of Chicago and has also taught there.

11. For a survey of the new growth theory up to the mid-1990s, see the symposium papers (Grossman and Helpman, 1994; Pack, 1994; Romer, 1994; Solow, 1994) that appeared in the Journal of Economic Perspectives.

12. See Nerdrum (1999) for a description of the development of the human capital theory. For a review of different approaches to measuring human capital in the growth literature, see Wößmann (2003) and Le et al. (2003).

13. Carlaw and Lipsey (2003) have recently argued that total factor productivity is not a good measure of technological change and proposed a growth model driven by general purpose technology. 
14. In Arrow's (1962) paper on learning by doing, he constructed a model with physical capital spillovers. For a comparison with Romer (1986) and Lucas (1988), Romer (1994) assumed that output for firm $i$ in the Arrow model can be expressed as $Y_{i}=A(K) F\left(K_{i}, L_{i}\right)$. In this expression, the level of technology, $A$, is a function of aggregate stock of capital.

15. A more apt title might be 'On the Mechanics of Economic Growth'.

16. Horwitz (2000) has recently offered an exposition of what Austrian macroeconomics would look like.

17. Even though Hayek (1945, p. 521) emphasized that 'scientific knowledge is not the sum of all knowledge' and identified the kind of 'knowledge of the particular circumstances of time and place' and further elaborated his analyses through Polanyi's introduction of tacit knowledge, it all became the purpose for illustrating the competitive market process. In the current growth-oriented atmosphere, it might be mentioned here that the discovery of tacit knowledge has linked it to another inquiry pertinent to growth or competitiveness (e.g. Leonard and Sensiper, 1998; Lawson and Lorenz, 1999; Maskell and Malmberg, 1999; Desrochers, 2001; Langlois, 2001; Howells, 2002).

18. For a discussion of the development of evolutionary economics, see Hodgson (1999, Ch. 6).

19. Sen (1992) has argued that traditional income inequality measures are inadequate measures for both egalitarian gains and failures. Even so, these measures can still be regarded as close substitutes for the perfect measures that might be developed in the future.

20. See http://www.census.gov/hhes/www/income/histinc/ineqtoc.html (Table IE-6).

21. These countries are Australia, Belgium, Canada, Denmark, Finland, France, Germany, Italy, Japan, the Netherlands, Norway, Sweden and the USA.

22. Using the WHO statistics, Stevens $(2004$, p. 4) estimates that diseases associated with poverty account for about $45 \%$ of the disease burden in the poorest countries.

23. Both disease eradication and global peace are actually considered important international (or global) public goods (Kaul et al., 1999; Ferroni and Mody, 2002). A pure international public good, in principle, can generate benefits that spill over borders, regions, ethnic groups and generations. It is quite conceivable that the provision of international public goods remains insufficient in the absence of an international government. In his presidential address to the AEA entitled 'International Public Goods without International Government', Kindleberger (1986, p. 11) commented that 'the system should be run at all times by rules, including regimes, not people'.

24. For Schumpeter, he was also a conservative but he 'acknowledged the power of Marx's vision of historical change' (Landreth and Colander, 1994, p. 390).

25. The field of 'institutional economics' claimed by the institutionalists to be their economic discipline can be divided into two strands: 'original' institutional economics (OIE) and 'new' institutional economics. The research of the OIE scholars extends back to the early works of Thorstein B. Veblen and John R. Commons. The new institutionalists are more associated with the mainstream neoclassical tradition and include several well-known scholars such as Ronald Coase, Douglass North and Oliver Williamson. For a detailed examination of the two major traditions of institutionalist thought in economics, see Rutherford (1994).

26. The lack of discussion of green accounting is a clear example of the mainstream's narrowness. Leading undergraduate macro texts such as Dornbusch et al. (2001) and 
Mankiw (2000) do not even mention a word on green accounting or green GDP. Leading graduate macro texts such as Barro and Sala-i-Martin (2004) and Blanchard and Fischer (1989) are preoccupied with mathematical models in dealing with the growth issue, not to mention the trivial green GDP (in their opinion).

27. To escape competition, the best strategy for older generations is the decision to use all the society's resources and not have any offspring. Obviously, this scenario has not yet occurred in human history.

28. I am grateful to Chiaen J. Wu for suggesting this figure.

29. This essay was collected in Keynes's work Essays in Persuasion (1963).

30. Daly (1996) provides a discussion about the conflict between long-term economic growth and the carrying capacity of the environment.

31. At the same time, many Americans have become more obese and suffer from associated diseases because of overeating and over-use of television and automobiles. The negative impact of over-consumption on the environment has long been recognized by environmentalists (see, for example, Jacobs, 1997). The mainstream literature has recently begun to explore this issue (Arrow et al., 2004).

32. Check the 'World Earth Day' (http://www.earthday.net) and the 'International Buy Nothing Day' (http://www.ecoplan.org/ibnd/ib_index.htm) movements, for example. The first Earth Day was organized by Denis Hayes and the late US Senator Gaylord Nelson in 1970 to raise public awareness to environmental crises. To date, Earth Day international network has now reached more than 12,000 organizations in 174 countries, while the US program has kept over 3000 groups and over 100,000 educators coordinating countless community development and environmental protection activities.

33. Indeed, before the Kyoto Protocol was to be negotiated in December 1997, the US Senate unanimously passed the Byrd-Hagel Resolution (S. Res. 98), sponsored by Democratic Party Senator Robert Byrd and Republican Party Senator Chuck Hagel, with a 95-0 vote in July 1997. The Resolution states that 'the United States should not be a signatory to any protocol to, or other agreement regarding, the United Nations Framework Convention on Climate Change of 1992, at negotiations in Kyoto in December 1997, or thereafter, which ... would result in serious harm to the economy of the United States' (S. Res. 98).

\section{References}

Aghion, P. and Howitt, P. (1992) A model of growth through creative destruction. Econometrica 60(2): 323-351.

Aghion, P. and Howitt, P. (1998) Endogenous Growth Theory. Cambridge, MA: MIT Press.

Ansuategi, A. and Escapa, M. (2002) Economic growth and greenhouse gas emissions. Ecological Economics 40(1): 23-37.

Armentano, D.T. (1999) Antitrust: The Case for Repeal (revised 2nd edn). Auburn, AL: Ludwig von Mises Institute.

Arrow, K.J. (1962) The economic implications of learning by doing. Review of Economic Studies 29(3): 155-173.

Arrow, K., Dasgupta, P., Goulder, L., Daily, G., Ehrlich, P., Heal, G., Levin, S., Mäler, K.-G., Schneider, S., Starrett, D. and Walker, B. (2004) Are we consuming too much? Journal of Economic Perspectives 18(3): 147-172.

Atkinson, R.D. and Court, R.H. (1998) The New Economy Index: Understanding America's Economic Transformation. Washington, DC: Progressive Policy Institute. 
Babe, R.E. (1994) The place of information in economics. In R.E. Babe (ed.), Information and Communication in Economics (pp. 41-67). Boston, MA: Kluwer Academic.

Babu, P.G., Kumar, K.S.K. and Murthy, N.S. (1997) An overlapping generations model with exhaustible resources and stock pollution. Ecological Economics 21(1): $35-43$.

Baetjer, H., Jr (2000) Capital as embodied knowledge: some implications for the theory of economic growth. Review of Austrian Economics 13(2): 147-174.

Barlett, D.L. and Steele, J.B. (1994) America: Who Really Pays the Taxes? New York: Simon \& Schuster.

Barro, R.J. and Sala-i-Martin, X. (2004) Economic Growth (2nd edn). Cambridge, MA: MIT Press.

Becker, G. (1964) Human Capital: A Theoretical and Empirical Analysis, with Special Reference to Education. New York: National Bureau of Economic Research.

Blanchard, O.J. and Fischer, S. (1989) Lectures on Macroeconomics. Cambridge, MA: MIT Press.

Boldrin, M. and Levine, D.K. (2002) The case against intellectual property. American Economic Review, Papers and Proceedings 92(2): 209-212.

Boulding, K.E. (1966) The economics of knowledge and the knowledge of economics. American Economic Review 56(1/2): 1-13.

Boulding, K.E. (1969) Economics as a moral science. American Economic Review 59(1): $1-12$.

Brokensha, D., Warren, D.M. and Werner, O. (eds) (1980) Indigenous Knowledge Systems and Development. Lanham, MD: University Press of America.

Burniaux, J.-M., Dang, T.-T., Fore, D., Förster, M., d'Ercole, M.M. and Oxley, H. (1998) Income distribution and poverty in selected OECD countries. OECD Economics Department Working Papers 189, March.

Caldwell, B. (2004) Hayek's Challenge: An Intellectual Biography of F.A. Hayek. Chicago, IL, and London: University of Chicago Press.

Carlaw, K.I. and Lipsey, R.G. (2003) Productivity, technology and economic growth: what is the relationship? Journal of Economic Surveys 17(3): 457-495.

Carlaw, K., Oxley, L., Walker, P., Thorns, D. and Nuth, M. (2006) Beyond the hype: intellectual property and the knowledge society/knowledge economy. Journal of Economic Surveys 20(4): 633-690.

Conca, K. (2001) Green politics in the Bush era: anti-environmentalism's second wave. Dissent 48(3): 29-33.

Daly, H.E. (1973) The steady-state economy: toward a political economy of biophysical equilibrium and moral growth. In H.E. Daly (ed.), Toward a Steady-State Economy (pp. 149-174). San Francisco, CA: W.H. Freeman.

Daly, H.E. (1977) Steady-State Economics: The Economics of Biophysical Equilibrium and Moral Growth. San Francisco, CA: W.H. Freeman.

Daly, H.E. (1996) Beyond Growth: The Economics of Sustainable Development. Boston, MA: Beacon Press.

Daly, H.E. (2005) Economics in a full world. Scientific American (Special Issue) 293(3): $100-107$.

Dasgupta, P. (1998) Population, consumption and resources: ethical issues. Ecological Economics 24(2-3): 139-152.

Dei, G.J.S., Hall, B.L. and Rosenberg, D.G. (eds) (2000) Indigenous Knowledges in Global Contexts: Multiple Readings of Our World. Toronto: University of Toronto Press.

Desrochers, P. (1998) On the abuse of patents as economic indicators. Quarterly Journal of Austrian Economics 1(4): 51-74.

Desrochers, P. (2001) Geographical proximity and the transmission of tacit knowledge. Review of Austrian Economics 14(1): 25-46.

Diamond, J. (2005) Collapse: How Societies Choose to Fail or Succeed. New York: Viking. 
Dornbusch, R., Fischer, S. and Startz, R. (2001) Macroeconomics (8th edn). New York: McGraw-Hill.

Ekelund, R.B., Jr and Hébert, R.F. (1997) A History of Economic Theory and Method (4th edn). Singapore: McGraw-Hill.

Ellen, R., Parkes, P. and Bicker, A. (eds) (2000) Indigenous Environmental Knowledge and its Transformation: Critical Anthropological Perspectives. Amsterdam: Harwood Academic.

Farmer, M.C. (2005) Environmental consequences of social security reform: a second best threat to public conservation. Ecological Economics 53(2): 191-209.

Farmer, M.C. and Randall, A. (1997) Policies for sustainability: lessons from an overlapping generations model. Land Economics 73(4): 608-622.

Fernando, J.L. (2003) NGOs and production of indigenous knowledge under the condition of postmodernity. Annals of the American Academy of Political and Social Sciences 590: 54-72.

Ferroni, M.A. and Mody, A. (eds) (2002) International Public Goods: Incentives, Measurement, and Financing. Boston, MA: Kluwer Academic.

Freeman, S. and Polasky, S. (1992) Knowledge-based growth. Journal of Monetary Economics 30(1): 3-24.

Gadgil, M., Berkes, F. and Folke, C. (1993) Indigenous knowledge for biodiversity conservation. Ambio 22(2-3): 151-156.

Galbraith, J.K. (1992) The Culture of Contentment. Boston, MA: Houghton Mifflin.

Georgescu-Roegen, N. (1977) Inequality, limits and growth from a bioeconomic viewpoint. Review of Social Economy 35(3): 361-375.

Grossman, G.M. and Helpman, E. (1991) Innovation and Growth in the Global Economy. Cambridge, MA: MIT Press.

Grossman, G.M. and Helpman, E. (1994) Endogenous innovation in the theory of growth. Journal of Economic Perspectives 8(1): 23-44.

Harris, J.M. (2000) Introduction to part 2: power, knowledge, and institutions in development practice. In J.M. Harris (ed.), Rethinking Sustainability: Power, Knowledge, and Institutions (pp. 141-150). Ann Arbor, MI: University of Michigan Press.

Hayek, F.A. (1937) Economics and knowledge. Economica 4(13): 33-54.

Hayek, F.A. (1945) The use of knowledge in society. American Economic Review 35(4): 519-530.

Hayek, F.A. (1973) Law, Legislation and Liberty, Vol. 1: Rules and Order. Chicago, IL: University of Chicago Press.

Hayek, F.A. (1974) The pretence of knowledge. The Nobel Prize Lecture, 11 December.

Hodgson, G.M. (1999) Evolution and Institutions: On Evolutionary Economics and the Evolution of Economics. Cheltenham: Edward Elgar.

Horwitz, S. (2000) Microfoundations and Macroeconomics: An Austrian Perspective. New York: Routledge.

Howarth, R.B. (1991) Intertemporal equilibria and exhaustible resources: an overlapping generations approach. Ecological Economics 4(3): 237-252.

Howarth, R.B. and Norgaard, R.B. (1990) Intergenerational resources rights, efficiency, and social optimality. Land Economics 66(1): 1-11.

Howells, J.R.L. (2002) Tacit knowledge, innovation and economic geography. Urban Studies 39(5-6): 871-884.

Hui, K.-L. and Png, I.P.L. (2002) On the supply of creative work: evidence from the movies. American Economic Review, Papers and Proceedings 92(2): 217-220.

Hunt, E.K. (1992) History of Economic Thought: A Critical Perspective (2nd edn). New York: HarperCollins.

Jacobs, J.M. (1994) Earth honoring: western desires and indigenous knowledges. In A. Blunt and G. Rose (eds), Writing Women and Space: Colonial and Postcolonial Geographies (pp. 169-196). New York: Guilford Press. 
Jacobs, M. (ed.) (1997) Greening the Millennium? The New Politics of the Environment. Oxford: Blackwell.

Jones, C.I. (1995) R\&D-based models of economic growth. Journal of Political Economy 103(4): 759-784.

Kasper, W. and Streit, M.E. (1998) Institutional Economics: Social Order and Public Policy. Cheltenham: Edward Elgar.

Kaul, I., Grunberg, I. and Stern, M.A. (eds) (1999) Global Public Goods: International Cooperation in the 21st Century. New York: Oxford University Press.

Keister, L.A. (2000) Wealth in America: Trends in Wealth Inequality. New York: Cambridge University Press.

Keynes, J.M. (1963) Essays in Persuasion. New York: W.W. Norton.

Kindleberger, C.P. (1986) International public goods without international government. American Economic Review 76(1): 1-13.

Kirzner, I.M. (1997) Entrepreneurial discovery and the competitive market process: an Austrian approach. Journal of Economic Literature 35(1): 60-85.

Kurz, H.D. (1997) What could the 'new' growth theory teach Smith or Ricardo? Economic Issues 2(2): 1-20.

Lamberton, D.M. (1994) The information economy revisited. In R.E. Babe (ed.), Information and Communication in Economics (pp. 1-33). Boston, MA: Kluwer Academic.

Landreth, H. and Colander, D.C. (1994) History of Economic Thought (3rd edn). Boston, MA: Houghton Mifflin.

Langlois, R.N. (1985) From the knowledge of economics to the economics of knowledge: Fritz Machlup on methodology and on the knowledge society. In W.J. Samuels (ed.), Research in the History of Economic Thought and Methodology: A Research Annual, Vol. 3 (pp. 225-235). Greenwich, CT: JAI Press.

Langlois, R.N. (1991) Knowledge and rationality in the Austrian school: an analytical survey. In J.C. Wood and R.N. Woods (eds), Friedrich A. Hayek: Critical Assessments, Vol. IV (pp. 118-140). London and New York: Routledge,

Langlois, R.N. (2001) Knowledge, consumption, and endogenous growth. Journal of Evolutionary Economics 11(1): 77-93.

Lawson, C. and Lorenz, E. (1999) Collective learning, tacit knowledge and regional innovative capacity. Regional Studies 33(4): 305-317.

Lawson, R. (2006) An overview of green economics. International Journal of Green Economics 1(1/2): 23-36.

Le, T., Gibson, J. and Oxley, L. (2003) Cost- and income-based measures of human capital. Journal of Economic Surveys 17(3): 271-307.

Leonard, D. and Sensiper, S. (1998) The role of tacit knowledge in group innovation. California Management Review 40(3): 112-132.

Lessig, L. (2001) The Future of Ideas: The Fate of the Commons in a Connected World. New York: Random House.

Lin, B.C.-A. (2006) A sustainable perspective on the knowledge economy: a critique of Austrian and mainstream views. Ecological Economics 60(1): 324-332.

Lin, B.C.-A. (2008a) Human capital and knowledge. In P.A. O'Hara (ed.), International Encyclopedia of Public Policy, Vol. 4: Social, Environmental and Corporate Governance, forthcoming. Perth: GPERU.

Lin, B.C.-A. (2008b) Green politics. In P.A. O'Hara (ed.), International Encyclopedia of Public Policy, Vol. 4: Social, Environmental and Corporate Governance, forthcoming. Perth: GPERU.

Lucas, R.E., Jr (1988) On the mechanics of economic development. Journal of Monetary Economics 22(1): 3-42.

Machlup, F. (1962) The Production and Distribution of Knowledge in the United States. Princeton, NJ: Princeton University Press. 
Machlup, F. (1976) Hayek's contribution to economics. In F. Machlup (ed.), Essays on Hayek (pp. 13-59). New York: New York University Press.

Machlup, F. (1980) Knowledge: Its Creation, Distribution, and Economic Significance, Vol. I: Knowledge and Knowledge Production. Princeton, NJ: Princeton University Press.

Machlup, F. (1982) Knowledge: Its Creation, Distribution, and Economic Significance, Vol. II: The Branches of Learning. Princeton, NJ: Princeton University Press.

Machlup, F. (1984) Knowledge: Its Creation, Distribution, and Economic Significance, Vol. III: The Economics of Information and Human Capital. Princeton, NJ: Princeton University Press.

Mankiw, N.G. (2000) Macroeconomics (4th edn). New York: Worth Publishers.

Marinova, D. and Raven, M. (2006) Indigenous knowledge and intellectual property: a sustainability agenda. Journal of Economic Surveys 20(4): 587-605.

Maskell, P. and Malmberg, A. (1999) Localised learning and industrial competitiveness. Cambridge Journal of Economics 23(2): 167-185.

Meadows, D.H., Meadows, D.L., Randers, J. and Behrens, W.B. III (1972) The Limits to Growth. New York: Universe Books.

Meadows, D., Randers, J. and Meadows, D. (2005) Limits to Growth: The 30-Year Update. London: Earthscan.

Mill, J.S. (1965) Principles of Political Economy with Some of Their Applications to Social Philosophy (edited with an introduction by W.J. Ashley, first published in 1848). New York: Augustus M. Kelley.

Mokyr, J. (2002) The Gifts of Athena: Historical Origins of the Knowledge Economy. Princeton, NJ: Princeton University Press.

Murray, G. and Cook, I.G. (2002) Green China: Seeking Ecological Alternatives. London and New York: RoutledgeCurzon.

Myrdal, G. (1958) Value in Social Theory: A Selection of Essays on Methodology (edited by P. Streeten). London: Routledge \& Kegan Paul.

Myrdal, G. (1968) Asian Drama: An Inquiry into the Poverty of Nations, 3 volumes. New York: Pantheon.

Myrdal, G. (1974) What is development? Journal of Economic Issues 8(4): 729-736.

Myrdal, G. (1978) Institutional economics. Journal of Economic Issues 12(4): 771-783.

Myrdal, G. (1981) What is political economy? In R.A. Solo and C.W. Anderson (eds), Value Judgement and Income Distribution (pp. 41-53). New York: Praeger.

Neef, D. (ed.) (1998) The Knowledge Economy. Boston, MA: Butterworth-Heinemann.

Nelson, R.R. (1996) The Sources of Economic Growth. Cambridge, MA: Harvard University Press.

Nerdrum, L. (1999) The Economics of Human Capital: A Theoretical Analysis Illustrated Empirically. Oslo: Scandinavian University Press.

Newman, K.S. (1988) Falling from Grace: The Experience of Downward Mobility in the American Middle Class. New York: Free Press.

Newman, K.S. (1993) Declining Fortunes: The Withering of the American Dream. New York: Basic Books.

Norchi, C.H. (2000) Indigenous knowledge as intellectual property. Policy Sciences 33(3-4): 387-398.

Norgaard, R.B. (1994) Development Betrayed: The End of Progress and a Coevolutionary Revisioning of the Future. London and New York: Routledge.

Oakman, B. (1986) Patents: an Austrian perspective. Economic Papers 5(1): 74-81.

O'Connor, M. (1997) John Stuart Mill's utilitarianism and the social ethics of sustainable development. European Journal of the History of Economic Thought 4(3): 478-506.

OECD (1996) The Knowledge-Based Economy. Paris.

OECD (2002) Measuring the Information Economy. Paris. http://www.oecd.org/sti/ measuring-infoeconomy, accessed July 2005. 
OECD (2003) DAC Guidelines and Reference Documents: Poverty and Health. Paris.

Pack, H. (1994) Endogenous growth theory: intellectual appeal and empirical shortcomings. Journal of Economic Perspectives 8(1): 55-72.

Paganetto, L. (ed.) (2004) Knowledge Economy, Information Technologies and Growth. Burlington, VT: Ashgate.

Peterson, W.C. (1994) Silent Depression: The Fate of the American Dream. New York: W.W. Norton.

Plenderleith, K. (ed.) (2004) Indigenous Knowledge and Ethics: A Darrell Posey Reader. New York and London: Routledge.

Polanyi, M. (1958) Personal Knowledge: Towards a Post-Critical Philosophy. Chicago, IL: University of Chicago Press.

Porat, M.U. and Rubin, M.R. (1977) The Information Economy, 9 volumes. Washington, DC: US Government Printing Office.

Rainbow, S. (1993) Green Politics. New York: Oxford University Press.

Richards, D.G. (2002) The ideology of intellectual property rights in the international economy. Review of Social Economy 60(4): 521-541.

Romer, P.M. (1986) Increasing returns and long-run growth. Journal of Political Economy 94(5): 1002-1037.

Romer, P.M. (1990) Endogenous technological change. Journal of Political Economy 98(5): S71-S102.

Romer, P.M. (1994) The origins of endogenous growth. Journal of Economic Perspectives 8(1): 3-22.

Rubin, M.R., Huber, M.T. and Taylor, E.L. (1986) The Knowledge Industry in the United States: 1960-1980. Princeton, NJ: Princeton University Press.

Rutherford, M. (1994) Institutions in Economics: The Old and the New Institutionalism. New York: Cambridge University Press.

Schultz, T.W. (1963) The Economic Value of Education. New York: Columbia University Press.

Schumacher, E.F. (1973) Small is Beautiful: Economics as if People Really Mattered. London: Abacus.

Schumpeter, J.A. (1975) Capitalism, Socialism, and Democracy (first published in 1942, with a new introduction by Tom Bottomore) (1st Harper Colophon edn). New York: Harper \& Row.

Semali, L.M. and Kincheloe, J.L. (eds) (1999) What Is Indigenous Knowledge? Voices from the Academy. New York and London: Falmer Press.

Sen, A.K. (1992) Inequality Reexamined. New York: Russell Sage Foundation.

Söderbaum, P. (1999) Values, ideology and politics in ecological economics. Ecological Economics 28(2): 161-170.

Solow, R.M. (1956) A contribution to the theory of economic growth. Quarterly Journal of Economics 70: 65-94.

Solow, R.M. (1994) Perspectives on growth theory. Journal of Economic Perspectives 8(1): 45-54.

Stevens, P. (2004) Diseases of Poverty and the 10/90 Gap. London: International Policy Network.

Strobel, F.R. (1993) Upward Dreams, Downward Mobility: The Economic Decline of the American Middle Class. Lanham, MD: Rowman and Littlefield.

Strobel, F.R. and Peterson, W.C. (1997) Class conflict, American style: distract and conquer. Journal of Economic Issues 31(2): 433-443.

Tachibanaki, T. (2006) Inequality and poverty in Japan. Japanese Economic Review 57(1): $1-27$.

Thurow, L.C. (1999) Building Wealth: The New Rules for Individuals, Companies, and Nations in a Knowledge-Based Economy. New York: HarperCollins. 
United Nations (2005) Report on the World Social Situation: The Inequality Predicament. New York: Department of Economic and Social Affairs.

Van Den Bergh, J.C.J.M. (1996) Ecological Economics and Sustainable Development: Theory, Methods and Applications. Cheltenham: Edward Elgar.

Varian, H.R., Farrell, J. and Shapiro, C. (2004) The Economics of Information Technology: An Introduction. New York: Cambridge University Press.

Vaughn, K.I. (1990) The Mengerian roots of the Austrian revival. History of Political Economy (supplemental issue) 22: 379-407.

Vaughn, K.I. (1994) Austrian Economics in America: The Migration of a Tradition. New York: Cambridge University Press.

Wachtel, P.L. (1998) Overconsumption. In R. Keil, D.V.J. Bell, P. Penz and L. Fawcett (eds), Political Ecology: Global and Local (pp. 259-271). London and New York: Routledge.

Wall, D. (2006) Green economics: an introduction and research agenda. International Journal of Green Economics 1(1/2): 201-214.

Weatherford, J.M. (1994) Savages and Civilization: Who Will Survive? New York: Crown Publishers.

WHO (2006) Health and Economic Development in South-Eastern Europe. Paris: WHO Regional Office for Europe and Council of Europe Development Bank.

Winch, D. (2004) Thinking green, nineteenth-century style: John Stuart Mill and John Ruskin. In M. Bevir and F. Trentmann (eds), Markets in Historical Contexts: Ideas and Politics in the Modern World (pp. 105-128). New York: Cambridge University Press.

Wößmann, L. (2003) Specifying human capital. Journal of Economic Surveys 17(3): 239270.

World Bank (1997) Sharing Rising Incomes: Disparities in China. Washington, DC.

Yi, Z. (2001) China's Ecological Winter (in Chinese). Hong Kong: Mirror Books. 